\title{
ELECTION 2014 AND THE ANC'S DUET OF DOMINANCE AND DECLINE
}

\author{
Susan Booysen \\ Susan Booysen is Professor at the Wits School of Governance, \\ University of the Witwatersrand, Johannesburg \\ e-mail: sbooysen@icon.co.za
}

\begin{abstract}
The African National Congress (ANC) result in South Africa's national and provincial elections of 2014 sings in two voices - 'extraordinary repeat victory' and 'monolith in gradual decline'. The fact that the party continued to dominate, with $62 \%$ of the national vote, was a significant achievement in this fifth set of national-provincial elections in democratic South Africa. In none of these elections has the ANC polled below $60 \%$. Yet, from whatever angle its result is analysed, decline and decay are evident. The national result trend is one of serial decline over the last three elections. The opposition challenge came from both left and right and the ANC took losses on both flanks; turnout was down, as many of its supporters chose abstention over vote-switching; the ANC became more dependent on rural votes in an urbanising South Africa and results in the metropoles suggest further degeneration, unless the party invents turnarounds. A trend reversal remains possible, yet would be exceedingly difficult given the extraordinary campaign that was required to bring in the 62\% in 2014.
\end{abstract}

\section{INTRODUCTION}

Time stood still for the ANC in Election 2014. Judgements of shortfalls, deficits and malfunction in its 20 years in power were suspended and it was the time to recognise the party as having made a substantive difference to the face and texture of South African politics and society. It was the time to remember the ANC's role in the liberation struggle, the time to affirm that it is better trusted than opposition parties. Yet, it was also borrowed time. The party was being given another chance to put quality into delivery statistics, jobs into the promises of job opportunities, become more accountable and bring in exemplary leadership. 
Much was changing on the ground, both in politics and in the electorate. Election 2014 was the stage for the ANC to show how a strong, prolonged and wellresourced campaign could deliver an above- $60 \%$ result in the face of adversity. This result materialised, but the election served notice that the earth was slowly moving beneath the ANC. For the second time in a row the party suffered a four percentage point decline in national election results - from $70 \%$ in 2004, to $66 \%$ in 2009 and $62 \%$ in 2014. It could no longer be taken for granted that the bulk of South Africans' hearts and votes automatically belong to the ANC.

In no election since 1994 had the ANC had to work so hard, against such odds to keep itself elevated as a political family, held together by a thread of struggle history. The thread had become fragile. In the face of the travails of 20 years in power and substantial corruption the liberation dividend was no longer automatically associated with the party. The election result showed how both middle and working classes, who had been beneficiaries of the ANC's rule, had become willing to vote against the party.

This article dissects the story of the ANC in Election 2014 in four parts. It begins with the phenomenal election campaign, which was well resourced and nurtured by the celebration of both 20 years of democracy and the life and passing of Nelson Mandela. The party's 2012 centenary launched the 2014 campaign and its message, the 'Good Story' of transformation and delivery over 20 years anchored it. Secondly, the article analyses the campaign machinery that carried the 2014 quest and explores how an ANC that was no longer boosted by a unified Tripartite Alliance and powerful Youth League came to rely on large numbers of volunteers to fill much of the space. Thirdly, the article turns to the election results, dissects the trends and explores the explanations. Finally, it considers the implications of the result, which was a resounding electoral victory, with large national margins over opposition parties, yet with disquieting implications for the ANC. In an urbanising South Africa, its support base had become more rural, it had fragile outright majorities in major metropolitan centres, the KwaZulu-Natal vote bonuses of recent elections had started drying up and ANC majorities in protest communities were increasingly brittle. The analysis draws on the author's 2013-14 research into voter attitudes and on continuous monitoring of electionrelated developments.

\section{THE ROLLING ANC CAMPAIGN}

The ANC conducted a substantial campaign in adverse conditions. The 'Good Story' of 20 years of ANC government delivery and transformation was the topline message. It was incontrovertible that South Africa is a changed, improved place, and the message meshed readily with national and government narratives. 
Second-line was that the ANC remains the hope, the liberator and the party that is bigger than any contemporary stain on its name. This bond had to be renewed and brandished. The third line was that policies had to be presented as generating hope, especially for employment and relief from extreme poverty, and be as radical as possible in order to withhold campaign oxygen from the newly-formed Economic Freedom Fighters (EFF). Fourth-line was that there had to be sufficient reassurances that the ANC and its leadership were attending to corruption and that a page had been turned. This extended into the 'Hands off Zuma' campaign by the ANC in KwaZulu-Natal (KZN), unapologetic in its belief in its own son, with a long history, in trying circumstances, in the ANC as liberation movement and as a maligned and unfairly persecuted deputy-president of the country (see Ngalwa 2014a).

It was a long-haul campaign that fused with the centenary celebrations that started in January 2012, with mobilisation around ANC president Jacob Zuma's re-election and the party's national conference in Mangaung in December 2012; the long illness and passing, in December 2013, of Nelson Mandela and the national celebrations of 20 years of democracy. The four months of intense campaigning that started in early 2014 were merely the final stretch.

All the currency generated by this string of powerful events was used in the ANC's interactions with voters and opposition parties. The party had to counter multiple obstacles to its reputation as a 'caring and competent' former liberation movement and governing party. The main controversies that had to be countered centred on:

- Continuously failing economic policies and especially failure to reduce unemployment rates;

- The arms deal and charges against Zuma of personal corruption, racketeering and money laundering, which have persisted throughout his terms in office. The Democratic Alliance (DA) persevered and the Seriti Commission started its investigations into the controversial arms deal, while Zuma's first term ended with his escaping an impeachment debate in Parliament;

- The shooting by police of striking miners at Marikana and how this could square with a caring and accountable governing party;

- The debacle of the unauthorised landing at Waterkloof Airforce Base of a private plane carrying guests attending the wedding of a member the Gupta family, which is known to be close to Jacob Zuma, and how it displayed special privileges for special citizens, and thus inequality before the law; 
- The unfolding controversy around the high cost of the 'security features' installed at the president's private homestead in Nkandla in KZN, which raised issues of presidential accountability and drew condemnation in a report compiled by the public protector;

- An increase in violent community protest, coupled with local government and local representation failures; and

- Severe labour disputes, including the prolonged strike in the platinum belt, which resulted in the decline of the National Union of Mineworkers and the Congress of South African Trade Unions (Cosatu).

ANC campaigners conceded that it was a demanding campaign to run (ANC elections head Malusi Gigaba in Musgrave, 2014; in Marrian 2014).

\section{Campaigning and the state of the ANC-people bond}

The ANC worked hard to persuade existing supporters to stay on board and boasted that it would increase its support across the provinces (Booysen 2013b). In defensive rather than expansive mode, it had to shore up its core constituencies. In this context, the minorities were largely inconsequential additions to the campaign.

While it tried to win over coloured voters, using arguments of DA racism, early in the campaign it stated that it would be a 'waste of time' to canvass whites (Du Plessis \& Ndlangisa 2013). Zuma's words (2014a) at the official 20 years of democracy celebration showed how difficult it was for the ANC to keep alive the hope of getting a job, and hinted at the odds against the ANC adding new working-class support:

Over the past 20 years employment, both formal and informal, has grown by around 5.6 million people, which is far faster than was the case previously. More work however still needs to be done to expand the capacity of our economy to absorb more people, especially the youth.

South African voters, who, in large numbers, continued to want to believe in their ANC, bolstered the campaign. Given its liberation legacy and performance in transforming the country, supporters were largely prepared to continue loving their family-like party, despite a lack of regard for its leadership and government (Booysen 2013a). Incumbency and patronage had become interlocked with the notions of the caring parent. Then-MP Ben Turok (interview with Ndenze 2014b) confirms the contemporary variations on the continuous bond: '... the African 
people of South Africa love the ANC. They don't love Zuma. The ANC is your family. The ANC is your neighbour, the ANC is your mother and father.'

The ANC largely still benefited from the culture among its followers (Booysen 2011) come election time to close ranks against an opposition party of choice and re-celebrate 1994. Nevertheless, the entry of the EFF to the left meant that the ANC had to refocus to counter both the DA and the EFF, despite its contention that it was unperturbed and used to 'a new opposition party per election'. It had seen the heydays of the United Democratic Movement (UDM) and the Congress of the People (Cope), both modest, one-election wonders. The EFF, however, was speaking to a growing audience of largely young and disaffected voters, was withholding new first-time voters from the ANC and had more legitimacy amongst the ANC's target audience than the predecessor split-off parties.

On the ground ANC campaigners were confronted with citizens who were critical of campaign promises and absentee representation (see Booysen 2013a). They confronted ANC leaders, interrogated them and insisted on explanations for insufficient or uneven delivery (most would close ranks and vote ANC at a later stage). ANC leaders used 'dirty tricks' when the going got tough. Nomvula Mokhonyane told protesters in Bekkersdal that the ANC did not need their 'dirty votes'; Malusi Gigaba called the DA a 'party of demons'; Fikile Mbalula averred that the Western Cape was 'run by witches' and that 'tokoloshes' were needed to run the DA's provincial government out of power; Baleka Mbete suggested that the struggle spirits would deal with those who were disloyal and Jacob Zuma and Cyril Ramaphosa warned voters that their ancestors would turn on them if they do not vote ANC (see The Sunday Independent, 13 April 2014, p 4; City Press, 13 April 2014, p 3; The Star, 20 April 2014, p 4). A member of the KZN ANC provincial government told voters: 'Nxamalala [Zuma] has increased grants, but there are people who are stealing them by voting for opposition parties' (see Hans, Jansen \& Padayachee 2014).

ANC supporters again showed that they do not automatically blame the organisation for the shortcomings of its leaders and leaders-in-government and ANC campaign strategists protected the president from being booed at rallies by audiences who wanted answers about issues like Nkandla or corruption rather than the official campaign narrative of the 'Good Story'. Zuma had been the object of booing at the memorial service for Nelson Mandela held in Gauteng in December 2013. In an effort to avoid a repeat sudden changes were introduced in campaign schedules, rallies with Zuma as the key speaker were minimised (see, eg, Ngalwa 2014b), he was moved to safer forms of campaigning and no-shows were induced (see Ngalwa 2014c).

The huge Siyanqoba national and provincial rallies became controlled events, with the audience seated in provincial blocks and records kept of who from 
which regions was attending. According to Turok (2014) '... the extraordinary measures taken to screen and control the crowd when the ANC released its election manifesto in January in Nelspruit may be a measure of how uneasy the leadership feels in the face of public discontent.'

\section{Convergence with ANC centenary and the state's 20 years of democracy celebrations}

The ANC's centenary celebrations in January 2012 were the de facto foundation of the rolling 2014 election campaign. The basic message was that it was the ANC that had brought liberation and far-reaching progress in a continuous liberation process. Failures in the first two decades of ANC governance were mere small diversions in the greater historical project. The story was one of progress, hope and trust.

Jacob Zuma, as incumbent ANC and South African president, took centre stage during the year-long festivities to remind South Africans not to forget the link between liberation and the ANC. The celebrations doubled as much of Zuma's campaign for re-election as ANC president in Mangaung in December 2012. By now Zuma could hardly be extricated from the ANC, even if it was clear that his presence was reducing its support, perhaps by as much as five percentage points (Pollster interview 2014).

ANC secretary-general Gwede Mantashe saw attacks on Zuma as efforts to destroy the ANC and defended the president as the symbol of the ANC, the head of a snake: 'If you want to kill a snake you crush its head ... The party is not something to play around with' (Ndenze 2014c).

The campaign gained substantial benefits from its links with the government's all-encompassing celebrations of 20 years of democracy (see section on state resources below). The way that a multitude of government departments presented the feats of 20 years articulated perfectly with the ANC's 'Good Story'. The best part of this story for the ANC was that vast amounts of state funds could be channelled legitimately into campaigns that doubled as the ANC election campaign.

\section{The passing of Nelson Mandela}

The passing of an iconic leader of the ANC's struggle against apartheid oppression, who had become the symbol of the democratisation and reconciliation process of 1994, was manna from heaven for the ANC's election campaign. The attention focused on Mandela frequently highlighted all that came to be seen as virtuous 
about the ANC. The ANC could be promoted as the embodiment of Nelson Mandela (see Ranchod 2013, pp 161-63).

There were several reports, backed by personal communication (Mandela family member 2013), confirming that Nelson Mandela, for an amalgam of reasons including family disputes and ANC political resourcefulness, was medically sustained to live from July to December 2013. The time of his passing served the ANC's election campaign. It came during a relatively quiet spell prior to the main campaign period and left December 2013 for major memorial services and respectful mourning. It also came just prior to the finalisation of the ANC's candidate lists. The focus on Mandela helped elevate the ANC campaign above the reaffirmation of Zuma as the face of the ANC's election quest.

\section{The 'Good Story' - heart of the ANC's campaign message}

The ANC's campaign message was 'a Good Story to tell' (see Seery 2014; Figure 1) in which 'us' (those experiencing the changes) are contrasted with 'them' (those who are not telling the truth about South Africa today). It ended with the line 'Together we move South Africa forward'. Despite criticism of this 'Good Story' as a half-truth and despite the dark side of the story, the narrative became ingrained in the 2014 campaign. No South African, even those hostile to the ANC, could disagree with aspects of the 'story': South Africa, warts and all, was a better place than it had been in the apartheid days.

This core campaign message refocused negative pre-election debates concerning the ANC. As the ANC's head of elections, Malusi Gigaba, remarked in an interview:

We knew we were not going to outcompete negative public debate and discourse about the ANC. We didn't even try to contest all the negative views that were being peddled at the media level. Our focus was getting down to the voters

Shoba 2014a

The 'Good Story' covered the entire 20-year period of ANC rule - the ANC would not be drawn on what proportion had been accomplished in the time of Zuma - and voters were reminded that Zuma had assumed power in the aftermath of the 2008 global economic meltdown.

The 'Good Story' complicated opposition party campaigns. The DA had hoped to extend its support (more substantially than it eventually did) into the black-African voter bloc to capture disaffected ANC support. It could not risk alienating potential converts by being hostile to the early days of democracy. 
Instead, it focused its campaign on the woes that had befallen South Africa and the ANC under Zuma's rule. ANC campaigners countered that the DA had also criticised the ANC in the pre-Zuma days.

The ANC was also aware that voters liked the party better than they liked its leadership (see Booysen 2013a). This became an essential part of the second-tier messaging. The South African Communist Party (SACP) ran poster campaigns urging citizens to vote ANC for the sake of Mandela and for the sake of Chris Hani. Zuma's face featured only on a modest portion of the posters, contrasting with the 2009 core poster, in which a confident-looking Zuma took up all the space.

\section{Figure 1}

ANC leaflet summarising the 'Good Story', the core message of campaign 2014

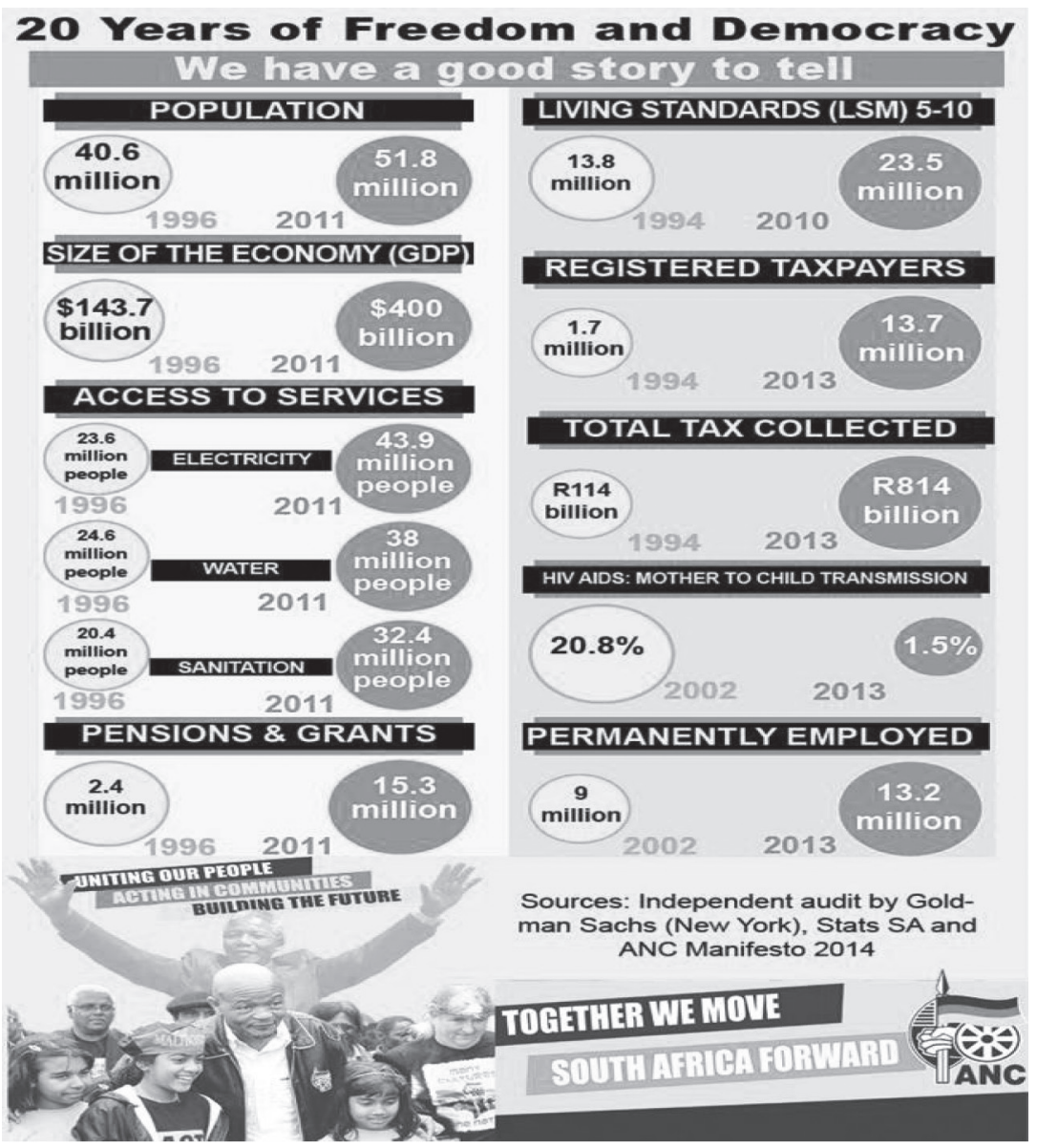




\section{'Making Nkandla go away'}

The ANC conducted its powerful campaign in the face of the recognised weaknesses of number one on its list, its president and repeat presidential candidate, Jacob Zuma, the most damaging of which related to the Nkandla issue. Much strategy went into minimising the impact of Nkandla, appealing to an electorate that largely regard the ANC as a bigger entity than its individual leaders (Booysen 2013a). In the end, the Nkandla-Zuma factor detracted from ANC support but did not fatally wound the party-movement's endorsement. The most significant impact of this was felt in Gauteng, where the ANC's vote dropped from $64 \%$ to $55 \%$.

The ANC maintained that voters were preoccupied with issues of basic service delivery and did not care about Nkandla. This contradicts the findings of a 2013 research project, which showed that citizens were hugely concerned about Nkandla; not to the extent of generally taking their vote away from the ANC, but certainly in ways that detracted from the legitimacy and credibility of the party (Booysen 2013a). Campaign coverage featured a host of reports of ANC leaders on the campaign trail being confronted by angry voters about corruption in government (see, eg, Seale 2014).

Gigaba shed light on how the ANC made Nkandla go away (see Marrian 2014). He argued that opposition campaigns that attacked Zuma backfired because the ANC was bigger than Zuma and that elections could not be treated as a referendum on Zuma. He also told Shoba (2014a) the DA's 'Ayisafani [the ANC is not the same]' advertisement was 'stupid' and in fact boosted the ANC: the DA 'invested millions of Rands of their own money on campaign adverts about the ANC. At that moment we in the ANC just had to sit back and say: "Oh, they are campaigning for us ..."'

Gigaba explained (see Marrian 2014) that the ANC began fashioning its Nkandla message in late 2013, before Public Protector Thuli Madonsela's report on the upgrades was leaked to the media. Subsequently the ANC emphasised the inter-ministerial report, which exonerated Zuma. Once the public protector's report was released in March 2014 the ANC used the inter-ministerial report to counterbalance the public protector's findings.

This approach was illustrated on the campaign trail in Mpumalanga. Zuma asserted that the opposition parties focused on Nkandla because they had no policies. 'All they say is iNkandla, iNkandla, iNkandla. This is because they have nothing to offer.' He claimed that the only thing the opposition parties knew about was taking matters to court and asked, 'how can we respect such people?' Zuma also maintained that Madonsela's report

didn't say the president misused money ... it did say there was something unclear with those who built and bought material ... 
Government asked the Special Investigating Unit to investigate ... the people who should be investigated.

Ndenze 2014a

Experts disagreed. The shielding of Zuma 'was a showcase of failing to address a political crisis in a very critical time before elections', argued political commentator Ibrahim Saleh. He added, however, that the ANC was like a religion, and even if members are horrified they are unlikely to change their religion (Dodds 2014).

\section{ANC CAMPAIGN MACHINERY}

By the time of Election 2014 the ANC had formidable resources, yet it had lost its unambiguous organisational high ground. The campaign apparatuses that pushed into the election battle were structurally weakened compared with those of previous elections. There had been crucial changes in the Tripartite Alliance; the youth, veterans and women's leagues were all incapacitated to some degree and luminaries and stalwarts fell by the wayside. Despite a growth in membership the SACP was no match for the organisational power of a strident Cosatu. Despite these organisational problems, the ANC pulled off a campaign of note. Two crucial replacement apparatuses came into effect - volunteers and a campaign drawing on state resources, including staff, projects and programmes, and advertising associated with the celebration of 20 years of democracy.

\section{Cosatu and Numsa}

Cosatu had long been essential to the ANC's campaigns, providing foot soldiers and resources through its organised formations but in 2014 Cosatu was divided and its powerful general secretary, Zwelinzima Vavi, had been silenced by the ANC for campaign purposes.

In addition, from late 2013 onwards, Irvin Jim, the general secretary of the National Union of Metalworkers of South Africa (Numsa), an affiliate union in the Cosatu federation, had warned that the union would not campaign for the ANC if the National Development Plan (NDP), which Numsa had rejected, featured in its election manifesto.

An ANC-led pre-election intervention delivered an accord that prevented further fallout at election time. Gigaba conceded that Cosatu infighting and Numsa's decision not to campaign for the ANC had affected the ANC campaign (see Marrian 2014). Subsequently, Numsa faced possible expulsion from Cosatu, standing accused of resisting Cosatu resolutions, for example, in not supporting the ANC in the elections. 


\section{The leagues, the stalwarts and the luminaries}

The three ANC leagues played reduced roles in the ANC's campaign in 2014 with the ANC Women's League (ANCWL) largely subdued and the ANC Youth League (ANCYL) non-existent, except for a marginal role played by the Youth Task Team, appointed to reconstruct a league in the place of the imploded body that had been led by Julius Malema and others who had left the ANC to form the EFF. In the past, and particularly in Election 2009, the ANCYL had been an election stalwart, driving grassroots campaigns and doing much of the footwork. The task team failed to activate the 4-million 'born-frees' (first-time voters born after 1994).

The Umkhonto weSizwe Military Veterans Association (MKMVA) had split roughly a year prior to the election. The split-off Umkhonto weSizwe War Veterans' Union (MKWVU) contested the election through the vehicle of the South Africa First political party, which had minimal resources and organisation and forfeited its election deposit. The MKWVU alleged (and substantiated) corruption in MKMVA (see Bailey 2012). The MKMVA put the fallout down to internal squabbling over positions and promised to mobilise South Africans to vote for the ruling party: 'We will occupy our defence posts and mobilise the people of South Africa to vote for the African National Congress' (Stone \& Gernetzky 2013).

Luminaries, among them Nobel Peace Laureate Archbishop Emeritus Desmond Tutu, declared that they would not support the ANC because it had lost its moral authority. 'I will not vote for them ... I say it with a very sore, very heavy heart because on the whole they have tended to be close to the kind of things we dreamt about,' he told a newspaper reporter (Smith 2014). Veteran and struggle stalwart Mavuso Msimang (2014) referred to the ANC's handing of the Nkandla affair as embarrassing and asked the ANC to 'put a stop to the cancer that causes power to be abused'. Others, such as former Cabinet minister Ronnie Kasrils and former deputy minister Nozizwe Madlala-Routledge, campaigned for a non-ANC vote (with exceptions) or a 'no vote'.

\section{Volunteers and door-to-door outreach operations}

ANC volunteers in their 2013-14 manifestation were a new formation, mobilised from mid-2013 onward. Volunteers had played a substantial role in previous elections, specifically in 2009, but their 2013-14 profiling was distinct. They were organised in each province, with huge launches and toolkits of typical queries and appropriate answers (Booysen 2013b). Jacob Zuma described them as an 'important additional structure in the ANC'. The 2013 launch statements referred to them as disciplined, no-stipend, campaign implementation forces activated at voting district level and subject to ANC branch executives. 
The brigades were baptised in the names of icons of the armed struggle (Booysen 2013b). Gauteng's 6 000-strong Moses Kotane Brigade was launched in Johannesburg in June 2013. The Western Cape had the Chris Hani Detachment 5000 Volunteers Campaign. Volunteers were well integrated into KZN ANC politics, in the form of the Volunteer Corp Movement - called 'a re-launch of the 1952 Volunteers of Inkosi Albert Luthuli'.

Gigaba noted that

the biggest strength in the ANC lies in its ground capacity ... the existence of the sheer force of troopers of the ANC, who can get into every household and mobilise everyone. We relied on our volunteers to carry our message across ... That was the heartbeat of our campaign.

Shoba 2014a

In his address at the final Johannesburg rally Zuma (2014b) asserted that 'ANC leaders and volunteers have visited every corner of the country, humbly engaging our people'. The ANC claimed to have reached its targeted potential voters at least three times in the course of the campaign. Part of the outreach formula was to let Zuma himself go to carefully selected houses, as was the case in his door-to-door outreach in Mpumalanga and the East Rand of Gauteng (see Ndlangisa \& Harper 2014). Volunteer action extended into the ranks of municipal functionaries with control over local resources.

ANC elections manuals covered the final year of the extended campaign cycle. Activities were organised in phases, with the objectives of identifying potential ANC voters, ensuring that eligible citizens acquired identity documents, getting them registered in cooperation with mobile Electoral Commission of South Africa (IEC) units and getting them to the polls on election day (ANC Gauteng 2013). The phases were:

- Laying the foundations, nominations and research on the communities that will be canvassed, up to July 2013;

- Back to the people, until the end of 2013, doing the first round of outreach, listening and taking and answering questions;

- Mayihlome [prepare for battle], until mid-April, including voter registration and cooperation with the Department of Home Affairs to issue identity documents, followed up with registration, where necessary in cooperation with IEC mobile units;

- Siyanqoba [we are wining], mid-April until election week, mobilisation that included meetings in parks and community precincts, handing out pamphlets and putting up posters in workplaces; and 
- Election week, reminding voters to vote, or to transport them to polls. Taxi-transport was put in place and T-shirts and refreshments were often waiting for voters as they finished voting.

The ANC's strategy included obstructing opposition party campaigns. A Community Agency for Social Enquiry (Case) report gave a detailed analysis of the tactics (Case 2014). Among the incidents recorded was an attempt to prevent the EFF from holding its closing rally at the Atteridgeville Stadium in Pretoria, where the local authority faked essential stadium maintenance work after the EFF had booked and paid its deposit. More indirectly, at the exact time that the DA launched its 2014 election manifesto in Polokwane, a large contingent of ANC National Executive Committee members embarked on a door-to-door campaign in the province's five regions.

\section{Resources}

The ANC's expensive, high-profile campaign benefited not only from public resources but also from ample organisational funding. The total cost of the campaign is estimated at around R500-million. Hunter (2014) cited an ANC report that referred to the party's campaign having cost R450-million. That figure might not be exhaustive. The ANC spent in excess of R17-million on television advertisements alone (Speckman 2014); more than three million T-shirts were procured; a dedicated social network team went on the election trail with party leaders and officials; millions of election leaflets and pamphlets were produced and taxi services were procured to transport voters to the polls.

The ANC might have been weakened on some fronts, but in no preceding campaign had the state been as enabled to play a role. Multiple national and provincial government departments delivered services and handed out food parcels and other 'gifts' as close as possible to election time and campaign visits and the celebration of 20 years of democracy created high levels of awareness of the government's achievements.

Print and electronic media were deluged with celebratory advertisements and billboards and advertorials and building wraps amplified the message (see Pillay 2014). No opposition party could compete.

A range of advertisements also reinforced the images of the ANC's leadership. One of these was that of the South African National Defence Force, which carried pictures of defence force commanders-in-chief in the past 20 years, ending with the face of Zuma and the slogan '20 years of freedom and democracy' (see, eg, The Sunday Independent, 14 April 2014, p 5). This security sector contribution to the ANC's campaign was supplemented in the last two weeks of the election 
campaign with visible security cluster visits to protest hotspots. The cluster issued statements about securing peaceful elections for the whole country, while, in essence, safeguarding the ANC in its campaigning.

State agencies were also de facto election agents, with a rapid succession of official openings in the last three months of the campaign showcasing the ANC's delivery record. For example, in April 2014 President Zuma launched the Umzimvubu water project in the Eastern Cape, and the De Hoop dam in Limpopo (see Velaphi 2014). Schools, houses, bridges and power stations were officially opened, accompanied by generous community celebrations. The government budget for food relief grew by an additional R200-million (to a total of R419million) in the election year (Ndlangisa 2014).

The South African Social Security Agency (SASSA) and provincial departments delivered truckloads of campaign gifts (such as food parcels, blankets and bicycles) to communities in advance of campaign visits by ANC luminaries (see, eg, Aboobaker 2014; Olifant, Naidoo \& Hlongwane 2014). For many of these events people dressed in ANC gear were bused in (see Du Plessis \& Ndlangisa 2013). 'We are the real election agents,' remarked a senior SASSA official (2014) in a pre-election interview.

\section{RESULTS}

The ANC's 2014 election results were a 'Good Story' with an adverse side. Given the adverse electoral context, which often related directly to the ANC as an organisation and its leadership, its above- $60 \%$ result was a feat and contrasted with pre-election debates about the party, in particular its leadership and organisational ethics. The result must, however, also be interpreted with caution. It confirmed the ANC's serial decline and revealed the extent to which the party required massive resources and campaigning to sustain itself above $60 \%$. The winning $62 \%$ was also unevenly constituted.

Two of the ANC's biggest electoral assets are the fact that it is the repository of the electorate's trust and the fact that voters separate party and leaders, affording higher value to the party (Booysen 2013a). Opposition parties made inroads into the ANC base, testifying to some shifting trust, but still lagged by large margins (Figure 2). Zuma's words (2014c) in response to the result rang true: '[T] his election victory has re-confirmed just how deeply rooted the ANC is in the hearts and minds of the overwhelming majority of South Africans.' Yet, Zuma (2014c) also over-interpreted the result as signifying that South Africans condoned Nkandla:

[t]hose parties who spoke so violently in Parliament ... spent more than a year discussing my homestead Nkandla, [i]nstead of telling 
us what they'll do for the country. They remind me of Shakespeare

... 'It is a tale / told by an idiot, full of sound and fury, / signifying nothing.'

\section{Table 1}

National Results: Proportional Party Support across Nine National and Local Elections, 1994-2014

\begin{tabular}{|c|c|c|c|c|c|c|c|c|c|}
\hline $\begin{array}{c}\text { Parties } \\
\text { with } \\
\text { national } \\
\text { representation }\end{array}$ & ザ & 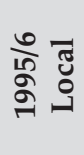 & જे & 용 త్ర & 冚 & 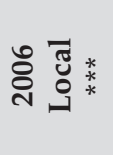 & ᄋे & 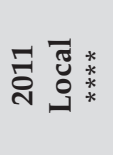 & 总 \\
\hline ANC & 62.6 & 58.0 & 66.4 & 59.4 & 69.9 & 67.7 & 65.9 & 62.9 & 62.2 \\
\hline $\mathrm{DA}\left(\mathrm{DP}+\mathrm{NP}^{*}\right)$ & 22.1 & 21.5 & 17.0 & 22.1 & 12.4 & 13.9 & 16.7 & 24.1 & 22.2 \\
\hline EFF & - & - & - & - & - & - & - & - & 6.4 \\
\hline IFP & 10.5 & 8.7 & 8.6 & 9.1 & 7.0 & 8.4 & 4.6 & 3.6 & 2.4 \\
\hline NFP & - & - & - & - & - & - & - & 2.4 & 1.6 \\
\hline UDM & - & - & 3.4 & 2.6 & 2.3 & 1.98 & 0.9 & 0.6 & 1.0 \\
\hline $\mathrm{FF}+(\mathrm{FF}+\mathrm{CP})$ & 2.2 & 2.7 & 0.8 & 0.1 & 1.0 & 1.0 & 0.8 & 0.4 & 0.9 \\
\hline Cope & - & - & - & - & - & - & 7.4 & 2.2 & 0.7 \\
\hline ACDP & 1.2 & 1.4 & 0.8 & 0.4 & 1.6 & 1.2 & 0.8 & 0.6 & 0.6 \\
\hline AIC & - & - & - & & - & - & - & & 0.5 \\
\hline ID & - & - & - & - & 1.7 & 1.4 & 0.9 & - & - \\
\hline Agang SA & - & - & - & - & - & - & - & - & 0.3 \\
\hline PAC & 1.3 & 0.7 & 1.2 & 1.2 & 0.7 & 1.2 & 0.3 & 0.4 & 0.2 \\
\hline MF & - & 0.4 & 0.3 & 0.3 & 0.4 & 0.3 & 0.3 & 0.4 & 0.1 \\
\hline Azapo & - & - & 0.2 & 0.3 & 0.3 & 0.3 & 0.2 & 0.2 & 0.1 \\
\hline UCDP & - & - & 0.8 & 1.0 & 0.8 & 0.8 & 0.4 & 0.2 & 0.1 \\
\hline
\end{tabular}

Notes: * In some instances the IEC website combines the support for the DP and NP/NNP; the current table does not dissect it; ** Stated by the IEC website to be the percentage for the PR component of the local vote; ${ }^{* * *}$ Stated by the IEC website to be the percentage for the 'Party overall'; ${ }^{* * * *}$ Percentages on the PR ballot. 
While confirming the serial decline in ANC election results over the past three elections, the details (Table 1; Figure 2) also show that the 2014 result was at roughly the same level as the 2011 local election result. However, the local and national results work on distinct dynamics. In two consecutive national elections the ANC had declined by 4 percentage points at a time by 2014. Table 1 shows that the ANC does about 2 to 3 percentage points worse in the local election that follows the national. If this trend persists the ANC can be expected at best to touch $60 \%$ in the 2016 local elections. The DA generally gets better results in local than in national elections. The EFF in local election 2016 will mostly detract from the ANC vote, but will also keep some disaffected voters away from the DA.

In the 2009, 2011 and 2014 elections the ANC depended on a growth in support in KwaZulu-Natal to bolster its national averages. However, since 2011 this effect has become less robust.

The rest of the analysis centres on six anchors that illuminate the ANC's 2014 result and also posit cautionary points for the ANC in future elections.

- The ANC is registering a national trend of decline; the 2014 election is the second in a row in which this has happened (and the fourth consecutive election if one includes local elections);

- Reduced levels of turnout nationally and provincially were a form of alternative non-ANC voting, to the extent that they can be differentiated from apathy or total rejection of the system;

- Voting trends across the provinces varied and in the two most populous provinces, KwaZulu-Natal and Gauteng, the ANC had differing fortunes - in KZN it was salvaged, while, in Gauteng, although it retained a slim majority, it suffered a major dent;

- The voting tendencies of the middle classes affected the outcome, especially in the metro areas of Gauteng, and they will affect the ANC's future prospects;

- In the context of South Africa becoming a highly urbanised country, the metros delivered hair-raising results: either the ANC lost its outright majority or came close to losing it; and

- Reduced support for the ANC in trouble spots, which ranged from substantial concentrations of EFF support in Gauteng townships, to a handful of ANC ward losses to the EFF in North West informal settlement and mineworker communities. (One of the three wards won by the EFF was Madibeng Ward 26, which included Wonderkop, the site of the Marikana massacre. The other two wards in which the EFF emerged as the winner were in the Rustenburg municipality.) 
Figure 2

Elections 1994-2014 National and Local Result Trends for Main Political Parties

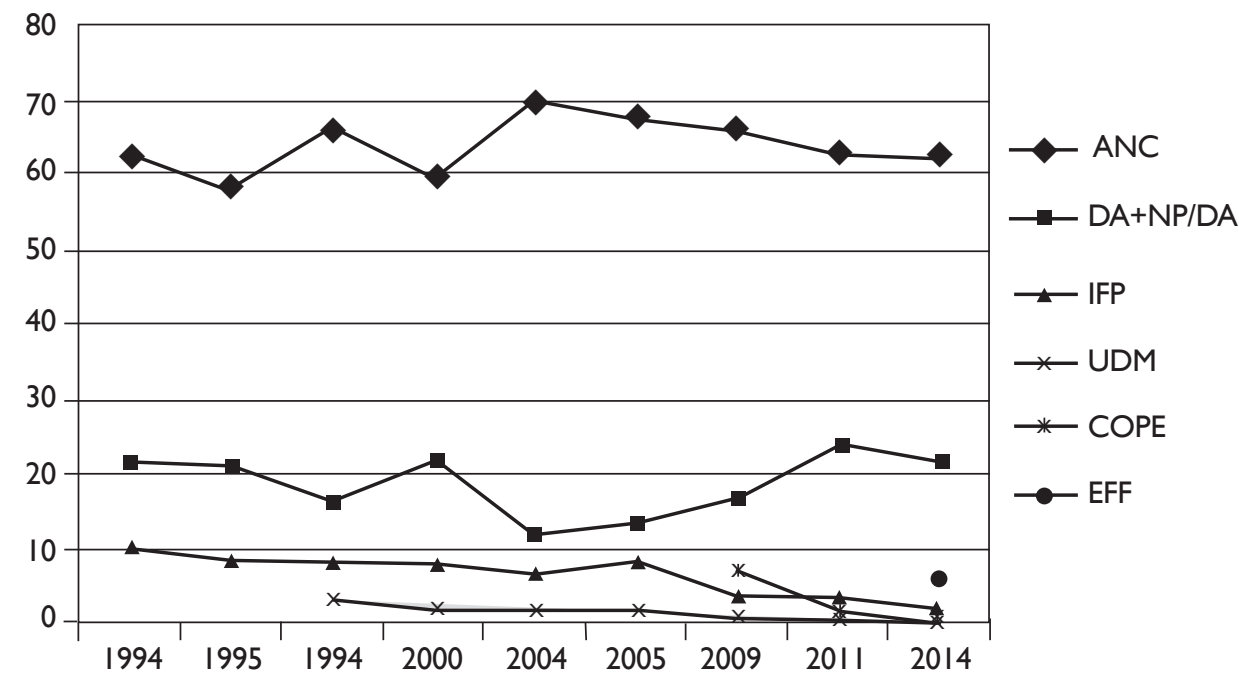

Note: Figure 2 focuses on the main parties; several other small parties hover in the 0.1 to $2 \%$ support band.

The duet of ANC dominance and decline

Election 2014 confirmed the ANC as the dominant party In South Africa. It won $62.15 \%$ of the vote, the support of about 11.5-million of 18-million voters and 249 of 400 National Assembly seats. This is impressive by most standards, yet it raises questions if one considers the party's famed liberation-movement invincibility, the amount of effort and resources required to leverage this continued dominance and the qualitative changes the opposition has undergone. Hence, the result of Election 2014 was the story of a gradually diminishing juggernaut (Figure 2) rather than another routine endorsement.

The ANC won 213827 fewer votes nationally in 2014 than it had in 2009 (and 235559 votes fewer across the provinces) - a 1.84\% decline if calculated in relation to the 11.7- million votes the ANC won in the previous national election. However, a total of 2.2-million names were added to the voters' roll between the 2009 and 2014 elections. Taking these into account the ANC's real national loss translated into a 10.4\% decline (Faull 2014; February \& Faull 2014).

This drop means that nationally the difference between the ANC and the largest of the opposition parties (the DA) slipped to just less than 40 percentage points for the first time since 1994. In 2004, at the peak of the ANC's national 
electoral power, the gap between it and the DA was 57 percentage points - a reduction therefore of close to 20 percentage points.

\section{Table 2}

ANC Results Relative to Voting Population

\begin{tabular}{|l|c|c|c|c|c|}
\hline \multirow{2}{*}{ Voting populations } & \multicolumn{5}{|c|}{ Election } \\
\cline { 2 - 6 } & $\mathbf{1 9 9 4}$ & $\mathbf{1 9 9 9}$ & $\mathbf{2 0 0 4}$ & $\mathbf{2 0 0 9}$ & $\mathbf{2 0 1 4}$ \\
\hline Voting age population (VAP) & $22.7 \mathrm{~m}$ & $22.6 \mathrm{~m}$ & $27.4 \mathrm{~m}$ & $30 \mathrm{~m}$ & $32.7 \mathrm{~m}^{*}$ \\
\hline Number of registered voters & \multirow{2}{*}{$\begin{array}{c}\text { No } \\
\text { VAP registered percentage }\end{array}$} & $18.2 \mathrm{~m}$ & $20.7 \mathrm{~m}$ & $23.2 \mathrm{~m}$ & $25.4 \mathrm{~m}$ \\
\cline { 4 - 6 } & \multirow{2}{*}{ Registration } & $80.4 \%$ & $75.4 \%$ & $77.4 \%$ & $77.7 \%$ \\
\cline { 3 - 6 } & & $89.3 \%$ & $76.7 \%$ & $77.3 \%$ & $73.5 \%$ \\
\hline Nurnout percentage & $19.5 \mathrm{~m}$ & $16.0 \mathrm{~m}$ & $15.6 \mathrm{~m}$ & $17.7 \mathrm{~m}$ & $18.4 \mathrm{~m}$ \\
\hline Turnout percentage of VAP & $86.0 \%$ & $71.8 \%$ & $57.8 \%$ & $59.8 \%$ & $57.1 \%$ \\
\hline VAP percentage for ANC & $53.8 \%$ & $46.9 \%$ & $39.6 \%$ & $38.8 \%$ & $35.0 \%$ \\
\hline
\end{tabular}

Source: www.elections.org.za, various windows

The ANC's national decline from 2009 to 2014 of about 4 percentage points must be seen in the context of Cope's implosion, which released the bulk of the $7 \%$ of 2009 national support back into the electoral marketplace. Cope lost a total of 1.19-million votes in this election and it is likely that at least 3 of the 7 percentage points reverted to the ANC. According to Kimmie, Greben \& Booysen (2010), 4 of the 7 percentage points Cope had won in 2009 had their origins in ANC support. Without this correction the ANC vote might have fallen below the $60 \%$ mark.

\section{Figure 3}

\section{Provincial Breakdown of the ANC's 2014 Vote in Relation to Voter Registration and Turnout}

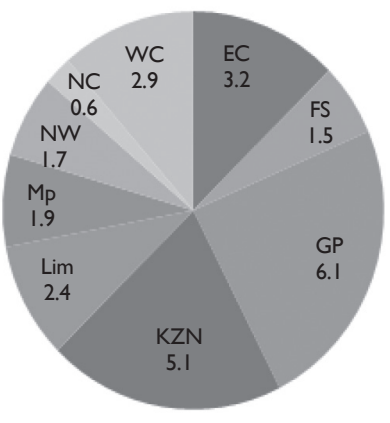

Registration (million)

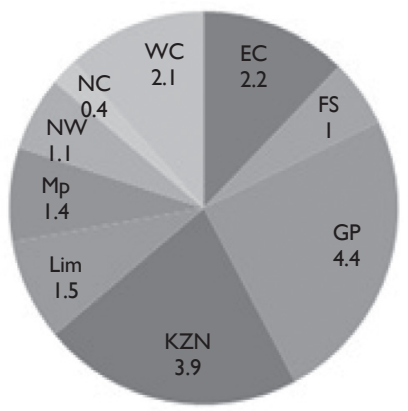

Turnout (million)

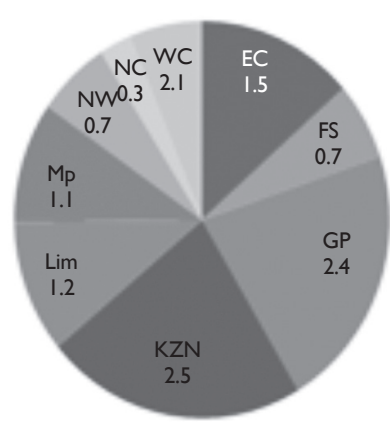

Votes for ANC (million) 


\section{The effect of the downturn in turnout}

According to Melber (2014) 'there is another, hidden story [to the election], documented by a $16 \%$ drop in the voter turnout over the last twenty years'. The turnout rate in the four elections since 1999 has been $89.3 \%, 76.7 \%, 77.3 \%$ and $73.5 \%$. Of a total of 25-million registered voters (with an estimated 10-million eligible voters, mainly the 'born frees', not bothering to register) one-quarter did not go to the polls in 2014, which means that the ANC governs with the active consent of only $35 \%$ of South Africans of voting age (Table 2).

Turnout had several types of impact on the ANC result (Figure 3). From previous research (Booysen 2013a) we know that ANC voters consider abstention as a mild form of opposition against their party. When they feel angry with or disaffected from the ANC they are (still) more likely to abstain than to switch to an opposition party. The author's detailed analysis of ward results shows that the ANC's top performances in terms of numbers of votes won came from wards with high turnout levels, many of them in the metropolitan areas of KwaZulu-Natal. In contrast, the wards in which the EFF gained its highest vote proportions tended to be those in which there had been a below-national-average turnout. Lower voter turnout nevertheless also muted the ANC's electoral slippage, given that disaffected voters did not add their votes to opposition party tallies.

The impact of the 'Sidikiwe' campaign, in protest against the current ANC, was uncertain. Some of the gains of the opposition parties might have been marginally linked to Sidikiwe. The proportion of national spoilt votes remained consistent - 251 960, only minimally higher than the 1999 figure (the percentage of spoilt ballots in 2014 was $1.4 \% ; 1.6 \%$ in 1999). Kasrils remarked that 'Sidikiwe!' succeeded in that 'we have created a national debate about blind loyalty [to the ANC]' (Forde 2014).

Differential provincial turnout affected the ANC result tangibly. In both Limpopo and the Eastern Cape the 2014 turnout was 6 percentage points down from that in 2009, and it was down by 5 percentage points in each of the Free State and Mpumalanga. The declines in these four provinces thus exceeded the 3.8 percentage point national drop. The changes are, nevertheless, dwarfed by the turnout in the 'big two', Gauteng and KwaZulu-Natal. The turnout in Gauteng was $76.5 \%$ (4 percentage points lower than 2009, yet still exceeding the national average). That in KwaZulu-Natal's was 76.9\% (4 percentage points lower than in 2009 but also still above the national rate). Thus the ANC continued to increase its share of the vote in KwaZulu-Natal but its share in Gauteng declined dramatically.

\section{The changing ANC proportions in the provinces}

The ANC's provincial proportions of the vote were up in four and down in 
five provinces. This was a nominal improved on 2009, when KZN was the only province in which the ANC increased its share. The 2014 provincial increases, however, were minor and only KZN added significant numbers. The ANC's KZN vote went up by 274579 votes from 2009 to 2014. This is modest, considering that the number of registered voters had increased by 2.2-million, yet it dwarfed the ANC's increases in the other provinces. The other three provinces with proportional increases were the Eastern, Northern and Western Cape.

The ANC won $22 \%$ of its national votes in each of Gauteng and KZN, showing the extent to which the politics of these two provinces led, on the one hand, to the erosion and, on the other, to the increase in the ANC's share of the vote in Election 2014: Gauteng contributed much of the decline, and KwaZuluNatal, for the third election in a row, went counter to the trend and brought in substantial numbers of additional votes.

\section{Table 3}

\section{ANC National and Provincial Election Results 1994-2014}

\begin{tabular}{|c|c|c|c|c|c|c|c|}
\hline \multicolumn{8}{|c|}{$\begin{array}{l}\text { All first-row figures in columns 2-6 are percentages and second rows are vote totals; } \\
\text { figures in columns 7-8 are percentage points }\end{array}$} \\
\hline ELECTION & $\begin{array}{c}1994 \\
\%\end{array}$ & $\begin{array}{c}1999 \\
\%\end{array}$ & $\begin{array}{c}2004 \\
\%\end{array}$ & $\begin{array}{c}2009 \\
\%\end{array}$ & $\begin{array}{c}2014 \\
\%\end{array}$ & $\begin{array}{c}\text { Change } \\
2009-2014\end{array}$ & $\begin{array}{c}\text { Change } \\
1994-2014\end{array}$ \\
\hline NATIONAL & 62.65 & 66.35 & 69.69 & 65.90 & 62.15 & -3.75 & -0.5 \\
\hline \multicolumn{8}{|l|}{ PROVINCES } \\
\hline Eastern Cape & $\begin{array}{c}84.4 \\
(2.5 \mathrm{~m}) \\
\end{array}$ & $\begin{array}{c}73.8 \\
(1.6 \mathrm{~m}) \\
\end{array}$ & $\begin{array}{c}79.3 \\
(1.8 \mathrm{~m}) \\
\end{array}$ & $\begin{array}{c}68.8 \\
(1.6 \mathrm{~m}) \\
\end{array}$ & $\begin{array}{c}70.8 \\
(1.6 \mathrm{~m}) \\
\end{array}$ & +2 & -13.6 \\
\hline Free State & $\begin{array}{c}76.6 \\
(1.0 \mathrm{~m}) \\
\end{array}$ & $\begin{array}{c}80.8 \\
(881 \mathrm{k}) \\
\end{array}$ & $\begin{array}{c}81.8 \\
(827 \mathrm{k}) \\
\end{array}$ & $\begin{array}{c}71.1 \\
(735 \mathrm{k}) \\
\end{array}$ & $\begin{array}{c}69.7 \\
(721 \mathrm{k}) \\
\end{array}$ & -1.4 & -6.9 \\
\hline Gauteng & $\begin{array}{c}57.6 \\
(2.4 \mathrm{~m}) \\
\end{array}$ & $\begin{array}{c}67.9 \\
(2.5 \mathrm{~m}) \\
\end{array}$ & $\begin{array}{c}68.4 \\
(2.3 \mathrm{~m}) \\
\end{array}$ & $\begin{array}{c}64.0 \\
(2.7 \mathrm{~m}) \\
\end{array}$ & $\begin{array}{c}54.9 \\
(2.6 \mathrm{~m}) \\
\end{array}$ & -9.1 & -2.7 \\
\hline KwaZulu-Natal & $\begin{array}{c}32.2 \\
(1.2 \mathrm{~m}) \\
\end{array}$ & $\begin{array}{c}39.4 \\
(1.2 \mathrm{~m}) \\
\end{array}$ & $\begin{array}{c}47.0 \\
(1.3 \mathrm{~m})\end{array}$ & $\begin{array}{c}63.0 \\
(2.2 \mathrm{~m}) \\
\end{array}$ & $\begin{array}{c}65.3 \\
(2.5 \mathrm{~m}) \\
\end{array}$ & +2.3 & +33.3 \\
\hline Limpopo & $\begin{array}{c}91.6 \\
(1.8 \mathrm{~m}) \\
\end{array}$ & $\begin{array}{c}88.3 \\
(1.5 \mathrm{~m}) \\
\end{array}$ & $\begin{array}{c}89.2 \\
(1.4 \mathrm{~m})\end{array}$ & $\begin{array}{c}84.9 \\
(1.3 \mathrm{~m}) \\
\end{array}$ & $\begin{array}{c}79.0 \\
(1.2 \mathrm{~m}) \\
\end{array}$ & -5.9 & -12.6 \\
\hline Mpumalanga & $\begin{array}{c}80.7 \\
(1.1 \mathrm{~m})\end{array}$ & $\begin{array}{c}84.9 \\
(959 k)\end{array}$ & $\begin{array}{c}86.3 \\
(959 \mathrm{k})\end{array}$ & $\begin{array}{c}85.6 \\
(1.1 \mathrm{~m}) \\
\end{array}$ & $\begin{array}{c}78.8 \\
(1.4 \mathrm{~m}) \\
\end{array}$ & -6.8 & -1.9 \\
\hline Northern Cape & $\begin{array}{c}49.7 \\
(201 \mathrm{k}) \\
\end{array}$ & $\begin{array}{c}64.3 \\
(211 \mathrm{k}) \\
\end{array}$ & $\begin{array}{c}68.8 \\
(219 \mathrm{k}) \\
\end{array}$ & $\begin{array}{c}60.8 \\
(246 \mathrm{k}) \\
\end{array}$ & $\begin{array}{c}63.9 \\
(279 k) \\
\end{array}$ & +3.1 & +14.2 \\
\hline North West & $\begin{array}{c}83.3 \\
(1.3 \mathrm{~m}) \\
\end{array}$ & $\begin{array}{c}80.0 \\
(1.0 \mathrm{~m})\end{array}$ & $\begin{array}{c}80.7 \\
(1.1 \mathrm{~m}) \\
\end{array}$ & $\begin{array}{c}72.8 \\
(784 \mathrm{k}) \\
\end{array}$ & $\begin{array}{c}67.8 \\
(764 \mathrm{k}) \\
\end{array}$ & -5 & -15.5 \\
\hline Western Cape & $\begin{array}{c}33.0 \\
(706 \mathrm{k})\end{array}$ & $\begin{array}{c}42.1 \\
(668 \mathrm{k})\end{array}$ & $\begin{array}{c}45.3 \\
(709 \mathrm{k})\end{array}$ & $\begin{array}{c}31.6 \\
(621 \mathrm{k})\end{array}$ & $\begin{array}{c}34.0 \\
(737 \mathrm{k})\end{array}$ & +2.4 & +1 \\
\hline
\end{tabular}

Source: www.elections.org.za, various windows 
The dividend of the gradual Inkatha Freedom Party (IFP) breakup continued to benefit the ANC. As the ANC became established in national electoral politics it also gained ground in KwaZulu-Natal, where it finally overtook the IFP in 2009. This progress continued in 2014. This time around the rise of the National Freedom Party (NFP), an IFP split-off party formed in 2011, aided the ANC nationally by splitting the remaining IFP support. The NFP was, nevertheless, a two-edged sword for the ANC. From the time of the 2011 local election it intercepted a proportion of the departing IFP support, thereby constraining the ANC's growth.

\section{Caught between middle-class ambiguity and working-class slippage}

Reflecting on the result patterns of the 2011 local elections Fakir \& Holland (2011) speculated that new class solidarities were emerging. This was reflected in the fact, among others, that a small percentage of socially upwardly mobile black South Africans had voted for the DA and raised the question of 'what disincentives social mobility represents for the ANC's continued political hegemony'. The 2014 results confirmed that the ANC was increasingly subject to the fracturing of both its middle- and working-class voting blocs.

The middle classes, argues the Gauteng ANC (2014), ' ... in this phase, are part of the motive forces of fundamental change. They are a by-product of the ANC's transformation agenda'. Yet the ANC noticed that the middle classes, including those who had benefited from ANC policies, did not all feel obliged to continue voting ANC. While the ANC continued to receive high-profile electoral endorsements from many of the newly enriched beneficiaries of its 20 years of rule, the 2014 results (especially in Gauteng) were a wakeup call about the middle classes' increasing willingness to vote against the party. Gwede Mantashe expressed the ANC's disappointment:

We describe the forces of the revolution as those who stand to benefit from change and those who are prepared to defend change ... If they vote for anybody else, it should not be because they are revolting because of an incident ... I find it strange for someone in the black middle class to neglect a party that promotes BEE and employment equity.

Heard 2014

The black middle classes were particularly important to the ANC in its Gauteng contest, as acknowledged in its own assessment of the performance of the Gauteng ANC in which it noted signs of multi-class snubbing of the party (ANC Gauteng 2014, p 6; Shoba 2014b) and emphasised the need to reverse these threats to ANC hegemony. 
'The ANC needs a comprehensive strategy to deal with [the middle-class] constituency, especially in the province where the black middle strata ha[ve] significant social, economic and political weight in determining the balance of power,' the party notes, naming as areas for attention the hostile reception of e-tolling on the province's roads, the cost of living, corruption and the slow pace of economic transformation. In the document the ANC also observes that while the working class generally sustains its electoral support for the party, large numbers voted against it in 2014, enabling the EFF to win 'an average of $10 \%$ of the vote in working-class townships, including the suburbs'.

These general electoral trends did not, however, cancel out the availability of many from both the 'ordinary middle classes' (the lower rungs of the middle class) and the highflying independently rich, or those enriched by black economic empowerment (BEE), to endorse the ANC. Many in these categories continued to see the party as a struggle icon and / or governing party that had earned their ongoing loyalty, others viewed it as a vehicle of opportunity for employment or enrichment.

At an event hosted by the Progressive Professionals Forum (PPF, a brainchild of the ANC), the contours of the party's vision of the new middleclass dynamic was sketched (see Poplak 2014). The PPF, along with the ANC's Progressive Business Forum, paraded professionals and aspirant BEEs in electoral endorsements of the ANC. The message was that the ANC brings prosperity to its associates. This message was also the theme of a pre-election ANC beach festival hosted by contentious tenderpreneurs $S^{\prime}$ bu and Shauwn Mpisane, with its slogan 'I'm young, smart and I vote ANC' (Mbuyazi 2014; Sosibo 2014), another demonstration of the rewards given to the ANC by the middle classes it indulges.

\section{The urban-rural trap and endangered metro support}

Trends in urbanisation, levels of ANC support typically linked to urban-rural status and differential urban and rural turnouts have an adverse impact on ANC support. The South African population is becoming more urban, while the ANC's urban vote has declined in comparison with its more stable rural vote.

Census 2011 calculated that $62 \%$ of the population of 51.8-million was urban. In contrast, among registered voters, $56 \%$ were urban and $44 \%$ rural; this proportion could increase for a closer match to the overall population. In addition, urban election turnout rose from $76 \%$ in 2004 to $80 \%$ in 2009, then returned to $76 \%$ in 2014. In comparison, rural turnout started higher than urban in 2004 (at 78\%), declined to 75\% in 2009 and declined further (to 70\%) in 2014 (see February $\&$ Faull 2014). The ANC is thus at an inherent disadvantage for the future. 


\section{Table 4}

\section{The ANC's Metro Decline - Select Cases}

\begin{tabular}{|c|c|c|c|}
\hline \multirow{2}{*}{ Metros } & \multicolumn{3}{|c|}{ Figures from the provinces } \\
\hline & $2009(\%)$ & $2014(\%)$ & Percentage point gain/loss \\
\hline \multicolumn{4}{|c|}{ Tshwane } \\
\hline ANC & 60.0 & 51.0 & -10.6 \\
\hline DA & 25.1 & 31.3 & +8.7 \\
\hline EFF & - & 11.4 & +10.1 \\
\hline \multicolumn{4}{|c|}{ Johannesburg } \\
\hline ANC & 62.4 & 53.6 & -10.1 \\
\hline DA & 21.8 & 29.8 & +10.6 \\
\hline EFF & - & 10.2 & +11.5 \\
\hline \multicolumn{4}{|c|}{ Ekurhuleni } \\
\hline ANC & 66.8 & 56.4 & -11.7 \\
\hline DA & 20.0 & 26.9 & +6 \\
\hline EFF & - & 10.7 & +10 \\
\hline \multicolumn{4}{|c|}{ Nelson Mandela Bay } \\
\hline ANC & 49.6 & 49.2 & -0.8 \\
\hline DA & 28.1 & 40.2 & +12.7 \\
\hline EFF & - & 4.3 & +4.2 \\
\hline
\end{tabular}

Source: www.elections.org.za, various windows

The ANC's greatest metropolitan vulnerability in 2014 was in Gauteng (see Table 4 ), a province in which more than $90 \%$ of the population live in the metros. Metropolitan results in other provinces - apart from the Eastern Cape's Nelson Mandela Bay - showed small declines only. The other ANC metropolitan results were, for 2009 and 2014, respectively and in percentages: Cape Town: 31.3 and 31.1; eThekwini: 66.3 and 64.6; Mangaung: 64.6 and 64.4; and Buffalo City: 67 and 66.9. The latter three metros all include notable tracts of rural areas.

In 2014 the ANC received $47.3 \%$ of its vote from rural South Africa, compared with $46.5 \%$ in 2009 and $48.7 \%$ in 2004 ; with $52.7 \%, 53.6 \%$ and $51.3 \%$ as the matching urban percentages (February \& Faull 2014). These internal ruralurban proportions have thus been relatively stable. However, when compared with the proportion of the national vote won by the ANC, urban decline stands out. Its proportion of the overall South African rural vote has remained relatively stable, only declining from $73 \%$ in 2004 to $71.3 \%$ in 2014 . However, there has been 
serial urban slippage: in 2004 the party won $67.8 \%$ of the urban vote, declining to $61.3 \%$ in 2009 and 55.8\% in 2014 (see February \& Faull 2014). In contrast, the DA's support is overwhelmingly urban, and the EFF made some of its main inroads in Gauteng's urban areas.

\section{Trouble-spot damage}

In protest communities generally the ANC lost more support than it did in communities that had not experienced protest in the six months prior to Election 2014. Overall, while support did not collapse, decline was evident and, in most instances, was greater in trouble spots than it was in non-protest communities (Booysen, De Waal, Ittmann \& Schmitz 2014). Several of the protest hotspots had also been prone to violent pre-election resistance to IEC voter registration and other electoral preparations, along with public embarrassments for the ANC during campaign visits.

It was tough going for the ANC in a range of protest-prone trouble spots. A widespread result in these protest areas was that although the ANC won the voting districts, it did so with reduced margins (O'Donovan 2014). In some instances turnout was low, in others opposition parties fared better than they did nationally. The ANC followed a dual strategy in its efforts to minimise damage. On the one hand, ministers in the justice, crime prevention and security cluster made a series of high-profile visits across provinces and claimed responsibility for stabilising the areas ahead of the elections. Many voters felt intimidated by the high security force presence, which included soldiers (see Mkhwanazi 2014), which promoted the image that the ANC government was in control but also contributed to a lower turnout.

On the other hand, the ANC made low-key visits to protest areas after initial hostile receptions, campaigning strategically and thereby minimising damage. Gigaba explained the approach (Shoba 2014a):

We went there [after the initial clashes with ANC representatives] when we had done our homework, even in Bekkersdal. After all the hype in Bekkersdal, we quietly campaigned. We quietly campaigned in Rustenburg among the miners. We engaged people away from the glare of the media ... We engaged people directly and talked to influential individuals and turned them around, and used those individuals to continue engaging the masses of our people. 


\section{CONCLUSION AND IMPLICATIONS FOR THE FUTURE}

The ANC continued to display impressive levels of dominance, nationally and in seven of the nine provinces, in the 2014 election, yet evidence of decline was scattered across the electoral landscape. This evidence was manifested in serial slippages in national proportions; in reduced turnout, provincial decay showed Gauteng as an Achilles heel and KwaZulu-Natal as the redeemer running out of steam; the ambiguity of the middle classes and damage to working-class support caused concern, along with increasing dependence on the shrinking base of rural votes, while fragility (albeit not collapse) ruled in protest communities. There was also concrete evidence of the ANC being in a quandary in the metropolitan areas, especially, but not only, in Gauteng.

ANC dominance persisted, but with doubts about its sustainability. While the party was far from being annihilated or losing power, it was unambiguously on the pathway to gradual decay. The DA is on a modest forward march, accumulating bigger proportions with each election and mildly pushing back the racial ceiling. The EFF added injury through its feats in ANC catchment areas and its potential to reach out to young and disaffected voters, on whom the ANC will depend should it hope to reverse 2014 declines. This situation may change, but both in Election 2014 and in its immediate aftermath there was little evidence of the ANC positioning itself for a reversal of the decline trends this article has analysed.

If the trend persists of the ANC generally winning a lower percentage of vote in local elections than in national elections, it is likely to slip below $60 \%$ in 2016. The message from Election 2014 was that the party's power and hegemony may soon be under serious threat. As Ndletyana (2014) asserts, '[a] calamitous fall is unlikely to set in dramatically. It will be incremental, but soon harden into a downward trend. The likely loss of three metros ... will herald that fatal turning point in 2016.'

The ANC circa 2014 benefited from an unsurpassed, possibly unsurpassable, election campaign. Should it be unable to leverage as much for its 2016 local and 2019 national-provincial campaigns the damage will be tangible - and the result below $60 \%$. Much of contemporary ANC power depends on it being seen to be the winner and in control of the renewal of its hegemony. With results that veer towards the loss of more of its outright majorities the decay will gain momentum.

In many respects the ANC's downward change appears gradual but relentless, given the disaffection among certain core voting blocs and the fact that in the post-election period it was sinking deeper into its pre-election problems. Yet the party is known for reinventing itself, for, on occasion, self-correcting. The question is whether it can dig deep and do what is best for the party and whether incumbent leaders have the ability to rise above self-interest. 
If clear signals of such a turn do not emerge, the metros will fall to opposition parties and will be followed by Gauteng. Without control over the economic centre, and with its fortunes anchored in rural South Africa and KwaZulu-Natal, the ANC will become a party with marginal electoral margins, yet entrenched in and fused with the state.

\section{- REFERENCES}

Aboobaker, S. 2014. 'State agency gives blankets at ANC rally'. The Sunday Independent, 6 April, p 1.

ANC Gauteng. 2013. Provincial Election Manual. Johannesburg, 5 May.

ANC Gauteng. 2014, Base document II: Framework document towards the ANC Gauteng $12^{\text {th }}$ Provincial Conference. Theme: 'United action to advance radical social and economic transformation'. Johannesburg, September.

Bailey, C. 2012. 'MK veterans form breakaway outfit'. The Sunday Independent, 2 December, $\mathrm{p} 6$.

Booysen, S. 2011. The ANC and the Regeneration of Political Power. Johannesburg: Wits University Press.

Booysen, S. 2013a. Twenty Years of South African Democracy: Citizen Views of Human Rights, Governance and the Political System. Johannesburg and Washington, DC: Freedom House.

Booysen, S. 2013b. 'ANC vote results in hands of volunteers'. The Sunday Independent, 9 June. Available at: www.iol.co.za/news / politics/ anc-vote-results-in-handsof-volunteers-1.1529442\#.U_upgWN6ino8 June 2013

Booysen, S, A de Waal, H Ittmann \& P Schmitz. 2014. 'Testing persistence of the dual repertoire hypothesis on Election 2014 data: Community protest still co-existing with ANC support?' Working Paper. Pretoria.

Community Agency for Social Enquiry (Case). 2014. Just Singing and Dancing. Research report. Johannesburg.

Department of Water Affairs. 2014. '20 years of water delivery for social and economic development'. The New Age, 21 March.

Dodds, C. 2014. 'Campaigns have been mediocre at best'. Saturday Star, 3 May.

Du Plessis, C \& S Ndlangisa. 2013. 'ANC won't waste its time on white votes'. City Press, 1 September.

February, J \& J Faull. 2014. 'Slicing and dicing the 2014 election data: What are the Implications for the ANC, DA and EFF?' Presentation.

Fakir, E \& W Holland. 2011. 'Changing voting patterns?' Journal of Public Administration 46(3.1) Special Issue: 2011 Local Government Elections.

Faull, J. 2014. Analysing South Africa's 2014 Election Results. Institute for Security Studies (ISS) Policy Brief 54, June 2014. 
Forde, F. 2014. 'Today's ANC had no moral cause, says Kasrils'. The Star, 11 May. Hans, B, L Jansen \& K Padayachee. 2014. 'Those voting for opposition parties "stealing grants"'. The Star, 9 April.

Heard, J. 2014. 'Mantashe's rules for clever blacks'. City Press, 16 June.

Hunter, Q. 2014. 'Elections cost battling ANC R450-million'. Mail \& Guardian, 28 November-4 December.

Kimmie, Z, J Greben \& S Booysen. 2010. 'A review of the 2009 South African election'. Politeia Special edition: Elections in Africa 29(1).

Mandela family member. 10 November 2013. Interview on condition of anonymity. Johannesburg.

Marrian, N. 2014. 'Cosatu infighting has affected ANC election campaign'. Business Day, 25 April.

Melber, H. 2014. 'And the Winner is?' Essay. Pretoria and Uppsala.

Mbuyazi, N. 2014. 'Mpisanes throw big beach party for ANC'. Independent, 3 May. Available at: ww.iol.co.za/ios / news / mpisanes-throw-big-beach-party-foranc-1.1683018\#.U_xnFWN6ino.

Mkhwanazi, S. 2014. 'Army stabilised "hot spots"'. The New Age, 3 June.

Msimang, M. 2014. 'ANC owes it to itself and SA to halt its abuse of power'. Business Day, 3 April.

Musgrave, A. 2014. 'ANC wants more time to fix Cosatu strife'. IOL, 13 August. Available at: www.iol.co.za/news/politics/anc-wants-more-time-to-fixcosatu-strife-1.1734611\#.U_unrGN6ino.

Ndlangisa, S. 2014. 'How the ANC won the elections'. City Press, 4 May.

Ndlangisa, S \& P Harper. 2014 'How ANC made Nkandla disappear'. City Press, 4 May.

Ndenze, B. 2014a. 'Zuma turns Nkandla into a joke'. The Star, 24 April.

Ndenze, B. 2014b. Interview with Ben Turok. 'Bumpy road ahead for ANC MPs'. The Star, 15 May.

Ndenze, B. 2014c. 'Zuma is head of the ANC and must be defended'. Saturday Star, 12 April.

Ndletyana, M. 2014. 'ANC stagnant in changing times'. The Sunday Independent, 25 May.

Ngalwa, S. 2014a. 'ANC calls in pros to sing Zuma's praises'. Sunday Times, 6 April. Ngalwa, S. 2014b. 'Zuma sticks to the poor and avoids the haters'. Sunday Times, 4 May.

Ngalwa, S. 2014c. 'Zuma booed by own party in Limpopo'. Sunday Times, 20 April. Nombembe, P. 2014. 'DA faces hefty legal bill after food-for-votes court bid fails'. Sunday Times, 4 May.

O’Donovan, M. 16 July 2014. Interview. Johannesburg.

Olifant, N, M Naidoo \& A Hlongwane. 2014. 'DA, ANC big guns out to woo voters'. The Sunday Independent, 6 April. 
Pillay, V. 2014. 'Gauteng ads show ANC's true colours', Mail \& Guardian, 11-23 January.

Pollster (anonymous). 2014. Interview. Major polling company. Johannesburg.

Poplak, R. 2014. 'Welcome to Fantasia - the ANC Manifesto endorsement and the reality left behind'. Daily Maverick, 30 April. Available at: www.dailymaverick. co.za / article / 2014-04-29-hannibal-elector-welcome-to-fantasia-the-ancmanifesto-endorsement-and-the-reality-left-behind / \#.U_uVyGN6joQ,

Ranchod, R. 2013. A Kind of Magic: The political marketing of the ANC. Johannesburg: Jacana.

SASSA official. 2014. Interview on condition of anonymity. Johannesburg, 23 April. Seale, L. 2014. 'ANC “Good Story" gets jeered'. The Sunday Independent, 13 April. Seery, B. 2014. 'ANC does deliver when it comes to poll advertising'. Saturday Star, 15 March.

Shoba, S. 2014a. " "Direct contact" strategy and avoidance of negative debate won it for the ANC'. Sunday Times, 11 April.

Shoba, S. 2014b. 'ANC concedes it lost middle class in Gauteng vote'. Sunday Times, 24 August.

Smith, D. 2014. ' "Desmond Tutu: why I won't vote ANC"'. The Guardian, 25 April. Available at: www.theguardian.com/world/2014/apr/25/desmond-tutumandela-wont-vote-anc

Sosibo, K. 2014. 'EFF, Nkandla unite ANC in KZN'. Mail \& Guardian, 2-8 May.

Speckman, A. 2014. 'Election windfall for ad industry'. Business Report, 8 May. Available at: www.iol.co.za/business/news/election-windfall-for-adindustry-1.1684990\#.VAMofGN6ino.

Stone, S \& K Gernetzky. 2013. 'MK veterans body rejects plan for new political party'. Business Day, 26 April. Available at: www.bdlive.co.za/national/ politics / 2013/04/26/ mk-veterans-body-rejects-plan-for-new-political-party.

Turok, B. 2014. With my Head above the Parapet. Cape Town: Jacana.

Velaphi, S. 2014. 'Zuma's water vow'. The New Age, 14 April.

Zuma, J. 2014a. Address on the occasion of the 2014 Freedom Day Celebrations, 27 April. Available at: www.dac.gov.za/content/address-president-jacobzuma-occassion-2014-freedom-day-celebrations.

Zuma, J. 2014b. Address to the ANC national Siyanqoba rally, 4 May, FNB stadium, Johannesburg.

Zuma, J. 2014c. Acceptance speech at the announcement of the 2014 election results, IEC National Results Centre, Pretoria, 10 May. Available at: www.anc.org. za/show.php?id=10898. 